\title{
Neocolonialism: the true intention behind the Northern Territory intervention
}

\section{Cameron Hart}

University of Technology Sydney, Faculty of Arts and Social Sciences, PO Box 123, Ultimo NSW 2017, Australia. cameron.hart@student.uts.edu.au

DOI: https://doi.org/10.5130/nesais.v4i1.1510

\begin{abstract}
While colonialism in Australia has 'officially' ended, it is evident that its impact on Indigenous people has been enduring. This essay argues that, beyond simply being 'legacies' of colonialism, latter-day interventions by Australian governments such as the Northern Territory Emergency Response Act are an insidious form of neo-colonialism.
\end{abstract}

Keywords: NT intervention; neocolonialism; white paternalism; the colonial gaze

\section{Introduction}

Throughout Australia's history, the nation has been defined by its violent legacy of colonialism, but according to Gillen \& Ghosh $(2007$, p. 5), while "colonialism officially ended decades ago ... the colonial legacy is still very powerful." Is it possible, however, that this 'legacy' and its enduring impact is simply colonialism reborn, transformed into a more sinister, more subtle, more deeply entrenched version of itself? This essay will seek to understand the history, context and consequences of the Northern Territory Emergency Response Act ('the intervention') as an indication of the enduring presence of colonial ideals within Australian society, known to be more accurately defined as neocolonialism - the new colonialism. It will achieve this understanding in several ways: firstly, by examining the decisions of the Howard Government which lead to the implementation of the intervention, and explore the representations of Aboriginal people under the colonial gaze. Subsequently, this essay will delve into rhetoric behind the intervention, namely the accounts of child sexual abuse documented in the Little Children Are Sacred report, as well as its other aspects, such as land seizure and policing of Aboriginal communities in the Northern Territory. Finally, the true face of the intervention — neocolonialism—will be revealed, analysed, and discussed.

\section{The Howard Era and Beyond}

Throughout his time as Prime Minister, John Howard engaged in numerous policy actions which 
adversely affected the lives of Aboriginal and Torres Strait Islander people. These have included the silencing of Indigenous voices in government through the discontinuation of Aboriginal and Torres Strait Islander Commission (ATSIC) and the abolition of self-determination policy, the abandonment of the Reconciliation movement, the Native Title Amendments Act and his refusal to offer a national apology regarding the Stolen Generations (Sherwood 2013, pp. 34-5). While her research thoroughly documents these political manoeuvres and their ramifications, Sherwood (2013, p. 36) unequivocally attests that his most destructive action as Prime Minister was the implementation of the Northern Territory intervention in August 2007.

Howard, on the other hand, in his own autobiography, described the intervention as receiving "massive public support, with a sense that at long last action had been taken to fix fundamental problems of law and order and health within Indigenous communities" (Howard 2010, p. 806). However, Macoun (2011, p. 520) makes note that "political justification and legitimation of the intervention ... [do not] reflect how Indigenous people and communities experienced the program," and thus create contention about the effectiveness and rationale behind the intervention, its effects, and the consequences of those effects as they continue to be perpetuated in the present day. Howard was unquestionably the driving force behind the paternalist government action, through his refusal of both apology and treaty. He did not "engage with the language of Indigenous sovereignty" (Brennan, Gunn \& Williams, 2004) because of the divisive idea that such a treaty would create one of "two separate nations" within the conception of Australia as a nation.

Yet the enduring outcomes of the intervention did not end when Howard's time as Prime Minister did, and even after Kevin Rudd's apology speech in 2008, the policy of intervention in the Northern Territory was not revoked (Sherwood 2013, p. 36). In fact, according to Pearson (2018), since Rudd's speech, the rate of Aboriginal and Torres Strait Islander children being removed from their homes has increased by approximately $65 \%$. This paints the apology and indeed the intervention in an interesting light. If the Australian government was truly 'sorry' about child removal, why did the rate of removals not decline? If there was remorse regarding the heinous treatment of Aboriginal families and communities, why not repeal the intervention? What does the Australian government have to gain? What are its true intentions? In order to answer these questions, we must first understand how Aboriginal communities are represented, how the children were 'saved', and why the intervention still continues.

\section{Aboriginal as Other: Representation Under the (Neo)colonial Gaze}

The Northern Territory intervention is a resurgence of the colonial ideology of the white man's burden, that Aboriginal and Torres Strait Islander people are unable to self-govern and are in need of 'protection' (Watson 2009, p. 55) by white settler authority (the Australian government). Macoun (2011, p. 520) explains Foucault's (1978) claim of discourse as a site of power relations in the context of the intervention, wherein Aboriginality holds the representation of being "in need of settlerimposed control". This relates to the viewpoint of Stokes (see below), in that Aboriginal and Torres Strait Islander people are disempowered through discourse; they are framed as "primitive and savage" natives (Chrisman 2004, p. 188; Brown \& Brown 2007, pp. 621-3) to be invaded, colonised, and inevitably civilised, while the British are invaders and colonisers; the bringers of that civilisation. 
From this idea, it is not difficult to see how "colonial knowledge purposely misrepresented and dehumanised Aboriginal people [and] produced and developed racial stereotypes" (Sherwood 2013, p. 29), many of which continue to be perpetuated. According to Brown and Brown (2007 p. 621), the mere presence of child sexual abuse in the Northern Territory, in colonial thought, is a manifestation of the "consequence of 'primitive' and 'barbaric' culture." Povinelli (2010, pp. 25-30) in part attributes this to the fallacies of a teleological assumption: that Aboriginality represents the past, and white settler society the future, therefore the assimilation or disappearance of Aboriginality under a white, colonial hegemony is not only guaranteed, but encouraged. The prominence of this temporal construction of settler society positions Aboriginal people as 'primitive' in that they are "an earlier and therefore lesser version of the European self' (Sheehan 2001, p. 7).

In the same vein, the tension this causes between Aboriginal and Torres Strait Islander people and the Australian government (or, in the colonial mindset, savage native against civilised settler) is exacerbated by the intervention itself. The notion of Aboriginal sovereignty has subsequently been a "source of political struggle both within Aboriginal communities and between them and the Australian state" (Stokes 1997, p. 169). While the Aboriginal communities of the Northern Territory grapple for their right to self-determination, the Australian government enacts legislation which characterises the Territory as "in need of development of assimilation into the settler order" (Macoun 2011, p. 523) because of the perceived incapacity of Aboriginal people to solve the problems within their own communities. However, Brown and Brown (2007, p. 621) note that while the response to the cases of the sexual abuse of children were met with "immense public horror" in the Little Children Are Sacred report, the findings did not acknowledge the voices within the Aboriginal communities who had been calling for action for decades, only to be ignored by government officials. This has seen a change in attitude regarding Aboriginality from 'a daily practice' to 'a problem to be solved', a problem which Aboriginal people are 'unable' to solve themselves, thus enhancing the need for neo-colonialist/settler intervention and solidifying Aboriginal representation under the colonial gaze.

\section{Neo-Colonial Logic: Saving the Savage from Itself}

As noted by Watson (2009, p. 45), the Little Children Are Sacred report identified widespread "community violence and the sexual abuse of children" of which Aboriginal communities themselves had not been unaware. Due to the devastating impacts of the Stolen Generations, "child protection and survival remain central to the fight for Aboriginal rights, identity, and cultural continuity" (Brown \& Brown 2007, p. 621), but in the report itself, there is a distinct lack of Aboriginal voices. From the perspective of the government, the intervention was represented as a crucial step in order to achieve "the opportunity for a better future", or in Prime Minister Howard's own words, "the obligation of caring for the young and vulnerable" (Howard in House of Representatives 2007a cited in Macoun 2011, pp. 521-2). Yet as earlier mentioned, child removal did not decline after the intervention, nor after Prime Minister Rudd's apology.

Sheehan (2001, pp. 30-1) observed prior to the intervention that violence in Aboriginal communities was often documented through the lens of white morality which invited readers to identify Aboriginal culture as the cause of sexual abuse and domestic violence, which would, in time, serve as supporting 
evidence for the intervention. However, while the children were depicted as "vulnerable victims of savagery", they also "provide additional moral justification for settler action" (Macoun 2011, p. 528). This contrasting depiction that child sexual abuse was the cause of an Aboriginal moral failing and would be solved by a white moral superiority was incorrect, as Anderson and Wild (2007, p. 57) identified that a substantial number of perpetrators against Aboriginal children were, in actuality, white. This suggests that the intervention was not solely about problems faced by Aboriginal communities themselves, nor the safety and wellbeing children who were suffering from violence and abuse. Evidence of this came to light after an investigation by Four Corners, uncovering the rampant cases of tear gas, chair-restraints, torture, and verbal abuse (Meldrum-Hanna \& Worthington, 2016). Yet even after a royal commission into youth detention in the Northern Territory (Royal Commission into the Protection and Detention of Children in the Northern Territory 2017) and despite recommendations that the detention centre be shut down, it remains open to this day, and no criminal charges have been made over the findings of the Commission (McGowan 2018).

\section{The True Intention behind the Intervention}

According to the work of Brown and Brown (2007, p. 621) "the federal government has 'delivered' the Northern Territory intervention, in rhetoric, as a means of protecting Aboriginal children," but based on discussion and analysis earlier in this essay, it is clear that this is not the only goal of the Federal Government. Primarily, the federal emergency response focused only on the Northern Territory-and only the Northern Territory has a federal Aboriginal land rights regime-which, according to Watson $(2009$, p. 46), is earmarked for a number of new uranium mines and transport routes. The intervention, coincidentally, also involved "compulsory land acquisitions" as noted by Brown and Brown (2007, p. 622). The fact that land acquisition is at the core of the intervention only further magnifies the immense neo-colonial ideology that dominates its implementation, and represents what Tilley (2012, p. 57) describes as "core colonial desires" to not only "occupy land" but to "sustain a sense of moral superiority in doing so". It is here that Aboriginality becomes a problem to the Federal Government, complicating colonial pursuit of exploitation of natural resources, land exploitation and, at its foundation, the dispossession of Aboriginal people (Macoun 2011, p. 527).

At its core, the intervention discriminates against Aboriginal people, hinders their capacity for selfdetermination and stigmatises their communities (ANTaR 2009 cited in Sherwood 2013, p. 36). For this reason, it is evident why the Federal Government suspended the Racial Discrimination Act 1975; if there had been no intention to racially discriminate, then there could be no plausible benefit of the suspension of the Act. This suggests that the intervention was a neo-colonial mission to civilise, under the guise of child welfare, in order to gain control of natural resources protected by the Northern Territory's federal land protection regime, but also to reassert control over Aboriginal communities.

In the opinion of Fanon (1968 cited in Chrisman 2004, p. 188), the Australian Federal government exhibits behaviour typical of the neo-colonial elite, particularly "their instrumentalisation of nationalist rhetoric to disguise their corruption and to stifle dissent" and what Memmi (1965 cited in Sherwood 2013, p. 35) identifies as "falsifying histories to imbue the coloniser with importance and superiority." This, unequivocally, clarifies the implementation of the intervention, specifically the actions which were inherently racist or did not complement the aim of reducing child sexual abuse, 
such as resource exploitation or land seizure. It also underpins the discursive dominance of the white settler authority (the Federal government) over the Aboriginal community's right to selfdetermination. Watson (2009, p. 47) identifies this as "a violent act which masquerades as being beneficial to impoverished Aboriginal communities across the [Northern Territory], but one that ... boils down to the legitimising of the right to invasion of Aboriginal lands and lives." With the benevolent illusion of the protection of children, the Federal Government has justified its actions in taking control of Aboriginal communities and their land in order to perform 'heroic' acts that appeal to white settler authority and morality, while undermining the autonomy of the Aboriginal communities of the Northern Territory.

\section{Final remarks}

Overall, it is evident that colonialism is still alive and well in Australia. To suggest otherwise - that the nation is anything other than neo-colonial - is to erase the enduring impacts of colonisation on Aboriginal and Torres Strait Islander communities and dismiss the injustices that are perpetuated against them, even as "state action to control the 'violent savage' is sanctioned" (Macoun 2011, p. 525). While the Australian Federal Government utilises a paternalistic rhetoric regarding the protection and wellbeing of children from sexual and domestic abuse, this has proven to be, if anything, more of a guise of white settler morality under which Aboriginal land can be seized and Aboriginal communities can be controlled, if the current child removal practices and the abuse at Don Dale Youth Correctional Centre are any indication. The focus on resource and land exploitation reveals the neo-colonial pursuits of the successive federal governments of Australia which, if anything, has progressed steadily in the decade since Rudd's apology speech. Despite the efforts of the Federal Government to seize Aboriginal land, it has always rightfully belonged to the Aboriginal and Torres Strait Islander people, as their sovereignty was never ceded.

\section{References}

Anderson, P. \& Wild, R. (2007), 'Ampe Akelyernemane Meke Mekarle (Little Children Are Sacred)', Report of the Board of Inquiry into the Protection of Aboriginal Children from Sexual Abuse 2007, Department of the Chief Minister, Northern Territory Government.

Brennan, S., Gunn, B. \& Williams, G. (2004), “Sovereignty' and its Relevance to Treaty-Making between Indigenous Peoples and Australian Governments', in Sydney Law Review, vol. 26, no. 3, accessed 16 June 2018, < $\underline{\text { http://www.austlii.edu.au/au/journals/SydLawRw/2004/15.html>. }}$.

Brown, A. \& Brown, N. J. (2007), 'The Northern Territory intervention: voices from the centre of the fringe', in Medical Journal of Australia, vol. 187, no. 11/12, pp. 621-23. 
Chrisman, L. (2004), 'Nationalism and postcolonial studies, in Lazarus, N. (Ed.), The Cambridge Companion to Postcolonial Literary Studies, Cambridge University Press: Cambridge. https://doi.org/10.1017/CCOL0521826942.010

Dodson, M. (2003), in Grossman, M. (Ed.), The end in the beginning, Melbourne University Press, Melbourne.

Gillen, P. \& Ghosh, D. (2007), Colonialism and modernity, University of New South Wales Press Ltd, Sydney.

Howard, J. (2010), Lazarus Rising, Harper Collins Publishers, Sydney.

McGowan, M. (2018), 'Don Dale: no charges to be laid over royal commission findings', The Guardian, accessed 15 June 2018, < https://www.theguardian.com/australia-news/2018/may/24/dondale-no-charges-to-be-laid-over-royal-commission-findings $>$.

Macoun, A. (2011), 'Aboriginality and the Northern Territory Intervention', in Australian Journal of Political Science, vol. 46, no. 3, pp. 519-34. https://doi.org/10.1080/10361146.2011.595700

Meldrum-Hanna, C. \& Worthington, E. (2016), 'Evidence of 'torture' of children held in Don Dale detention centre uncovered by Four Corners', $A B C$, accessed 15 June 2018, < http://www.abc.net.au/news/2016-07-25/four-corners-evidence-of-kids-tear-gas-in-don-daleprison $/ 7656128>$.

Pearson, L. (2018), '10 Things You Should Know about the National Apology', SBS, accessed 16

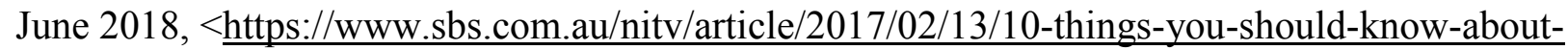
national-apology $>$.

Povinelli, E. (2010), 'Indigenous Politics in Late Liberalism, in Altman, J. \& Hinkman, M. (eds.), Culture Crisis, UNSW Press, Sydney.

Royal Commission into the Protection and Detention of Children in the Northern Territory (2017), Report to the Board of Inquiry into the Protection and Detention of Children in the Northern Territory, accessed 15 June 2018, $<\underline{\text { https://childdetentionnt.royalcommission.gov.au/Pages/Report.aspx\#_Report }>}$

Sheehan, N. (2001), 'Some Call it Culture: Aboriginal Identity and the Imaginary Moral Centre', in Social Alternatives, vol. 20, no. 2, pp. 29-33.

Sherwood, J. (2013), 'Colonisation - It's bad for your health: The context of Aboriginal health', in Contemporary Nurse, vol. 46, no. 1, pg. 28-40. https://doi.org/10.5172/conu.2013.46.1.28

Stokes, G. (1997), 'Citizenship and Aboriginality: Two Conceptions of Identity in Australian Political Thought, in Stokes, G. (ed), Politics of Identity in Australia, Cambridge University Press, Cambridge. https://doi.org/10.1017/CBO9781139166911.012 
Watson, I. (2009), 'In the Northern Territory intervention what is saved or rescued and at what cost?', in Cultural Studies Review, vol. 15, no. 2, pp. 45-60.

(c) (1) (C) 2018 by the author(s). This article is distributed under the terms and conditions of the Creative Commons Attribution license (http://creativecommons.org/licenses/by-nd/4.0/). 